\title{
Human personality and organ transplantation
}

\author{
Human personality and organ transplantation
}

\author{
Nicolae Popescu', Grigore-Alexandru Popescu², Ramona Gîdea ${ }^{3}$ \\ ${ }^{1}$ SC Psyho-Soma Med SRL, Drobeta-Turnu Severin, România \\ ${ }^{2}$ Spitalul Municipal Orşova, România \\ ${ }^{3}$ Spitalul Municipal Timişoara, România
}

\begin{abstract}
Lately, many studies, information and questions have emerged that transplanted organs carry the donor's personality. A series of theories have been launched on how some characteristics of the donor's personality come and change or add to the personality of the recipient, how they are transmitted from the transplanted organ (heart, lung, liver, kidneys, etc.) to the organ receiving the organ. Romanian scientist Stefan Odobleja was among the first scientists to say: „There are direct inter-organizational actions; each organ has relation-ships with all the other organs, including the brain“, intimating an analogy between psychic phenomena and quantum phenomena.
\end{abstract}

Keywords: transplant, personality, cell memory, resonance, quantum physics, consonant psychology

\section{REZUMAT}

În ultimul timp, au apărut multe studii, informaţii şi întrebări legate de faptul că organele transplantate poartă personalitatea donatorului. Au fost lansate o serie de teorii legate de modalitatea cum unele caracteristici ale personalităţii donatorului vin şi modifică sau se adaugă la personalitatea primitorului, cum se transmit acestea de la organul transplantat (inimă, plămân, ficat, rinichi etc.) la cel care primeşte organul. Savantul român Ştefan Odobleja a fost printre primii oameni de ştiinţă care a afirmat: ,,Există acţiuni interorganice directe; fiecare organ are relaţii cu toate celelalte organe, inclusiv cu creierul", intuind o analogie între fenomenele psihice şi fenome-nele cuantice.

Cuvinte cheie: transplant, personalitate, memorie celulară, rezonanţă, fizică cuantică, psihologie consonantistă

\section{INTRODUCERE}

Personalitatea umană reprezintă unul dintre cele mai complexe fenomene din Univers. Este o realitate extrem de complexă, deoarece integrează o varietate de componente diferite ca structură, funcţionalitate şi finalitate (biologice, psihologice, sociale, axiologice, istorice). Are şi un caracter dinamic, deşi dispune de trăsături relativ stabile, cunoaşte o evoluţie în timp, atât în plan filogenetic, cât şi în plan ontogenetic.

$\mathrm{Ca}$ urmare a acestui fapt, personalitatea nu poate fi cercetată de o singură ştiinţă, ci necesită o abordare multidisciplinară. Deşi ideea de personalitate are rădăcini foarte adânci în istoria vieţii şi culturii omeneşti, ştiinţa despre personalitate, psihologia personalităţii, este de dată recentă, deoarece nu este suficient să recunoşti manifestările personalităţii, ci şi să o studiezi riguros, să îi descifrezi structura şi modul de funcţionare.

Problema personalităţii ocupă azi un loc central atât în cercetările teoretice, cât şi aplicative. Cu toate acestea, în afară de inteligenţă, niciun alt concept al psihologiei nu este atât de complex şi nedeterminat precum cel de personalitate. În anul 1931, G.W. Allport enumera peste 50 de definiţii, iar astăzi McClelland găseşte peste 100 de definiţii ale termenului.

Se precizează că, la ora actuală, pot fi delimitate cu uşurinţă cel puţin 10-12 teorii despre personalitate. Printre cele mai cunoscute se numără: teoria psihanalitică (S. Freud, A. Adler, K. Jung ş.a.), teoria factorială (G. Allport), teoria personalistă (C. 
Rogers), teoria organismică, teoria socioculturală ş.a.

Nu ştim din ce motive a fost omisă teoria psihofizică expusă de Ştefan Odobleja (1938) în lucrarea sa monumentală „Psihologia consonantistă“.

Dacă, până în prezent, s-au formulat o multitudine de teorii în definirea personalităţii, astăzi afirmaţia că organele transplantate poartă personalitatea donatorului ne deschid alte provocări în modalitatea de formare a personalităţii umane.

\section{OBIECTIVE}

Prin această lucrare ne-am propus ca, printr-un studiu de tip observaţional, să analizăm conţinutul operei lui Ştefan Odobleja, să verificăm dacă ideile sale se regăsesc în descoperirile şi cercetările ştiinţifice medicale, teoretice şi aplicative actuale, în special pe spaţiul fenomenelor cuantice.

\section{DISCUṬII}

\section{Personalitate donator - primitor}

Până în prezent, au fost lansate o serie de teorii legate de modalitatea cum unele caracteristici ale personalităţii donatorului vin şi modifică sau se adaugă la personalitatea primitorului, cum se transmit acestea de la organul transplantat (inimă, plămân, ficat, rinichi) la cel care primeşte organul.

În cartea sa, „A change of heart", Sylvia Claire prezintă câteva cazuri care parcă ţin de domeniul SF. S-a făcut o paralelă între pasiunile pe care le avea donatorul şi ceea ce a devenit, după un transplant, beneficiarul. Şi-a însuşit o bună parte din personalitatea donatorului. Fără să aibă cunoştinţă de donator, beneficiarul a început să aibă aceleaşi preferinţe. Cum se poate explica faptul că un beneficiar a fost înainte de intervenţie vegetarian şi, după transplant, a revenit la consumul de carne?

S-au constatat schimbări în ceea ce priveşte personalitatea, gândirea, concepţia despre viaţă. Cercetătorii de la Universitatea Arizona au studiat 300 de subiecţi care au fost beneficiarii unei noi inimi. Cercetătorii susţin că informaţia şi energia sunt transmise electromagnetic intre creier şi inimă, creierul fiind capabil să proceseze prin rezonanţă magnetică informația primită de la inima donatorului.

O altă teorie susţinută de cercetătorii este teoria memoriei sistemice celulare, care a început să fie studiată după anii ' 90 . Toate celulele vii au memorie şi subsisteme funcţionale. Mai mult, recenta integrare a teoriei sistemelor cu conceptul de energie, numită „teoria dinamică a sistemelor energetice“, asigură o logică convingătoare conform căreia toate sistemele dinamice depozitează informaţii şi energie, în diferite grade.

Bucle de feedback recurent există în toate sistemele atomice, moleculare şi celulare, de aceea ar trebui să se găsească în aceste sisteme dovezi ale memoriei sistemice, atomice, ale memoriei sistemice celulare. Acest mecanism poate să facă o precizare, şi anume aceea că beneficiarii sensibili ai transplanturilor de organe pot experimenta aspecte ale istoriei personale a donatorului, depozitate în ţesuturile transplantate.

$\mathrm{O}$ altă teorie - care ar putea explica un mecanism al memoriei sistemice - este memoria microtubulilor, avându-i ca autori pe fizicianul Sir Roger Penrose şi anestezistul Stuart Hameroff. În urma unor studii, aceştia au descoperit vibraţii cuantice în interiorul unor structuri intracelulare numite microtubuli din neuronii cerebrali.

Această teorie a fost numită de autori ,orchestrated objective reduction“ (Orch OR), publicată la mijlocul anilor '90, teorie care stă şi la baza explicaţiei originii conştiinţei noastre, care reflectă natura existenţei noastre în Univers (fig. 1).

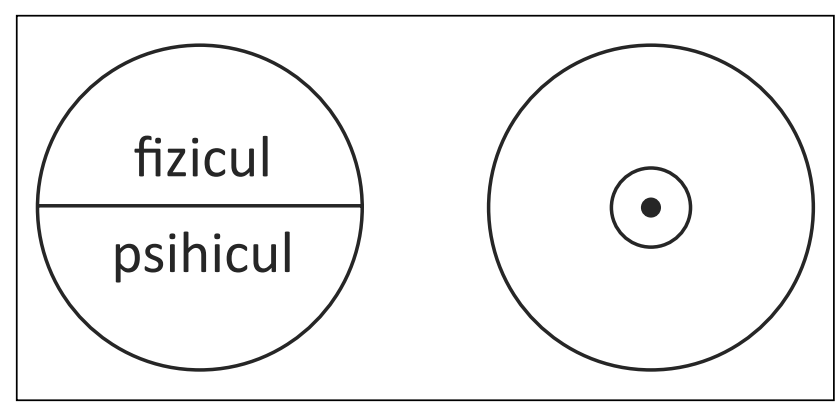

FIGURA 1. Universul văzut de Odobleja (2, p. 73) (Universul - cercul din figură - şi cele două jumătăți ale lui: fizicul şi psihicul; fizicul este exteriorul, perifericul, sfera mare; psihicul este interiorul, centralul, porțiunea mai mică dar cea mai importantă a universului fiecărei ființe).

\section{Fundamentarea vizionară a lui Ştefan Odobleja}

Toate preocupările pe baza teoriei cuantice a conştiinţei încearcă să explice sufletul uman ca structură fundamentală a universului. Revenind la Ştefan Odobleja, acesta afirma, încă din 1938, în lucrarea sa, că psihicul este o funcţie biologică localizată în creier şi că acesta este, ,fără îndoială, un organ privilegiat, dar el nu deţine monopolul comunicaţiilor interorganice“. Defineşte psihofiziologia ca fiind ,studiul repercusiunilor reciproce (interreacţiilor) între centru şi periferie, între fizic şi fiziologic, între moral şi corp, între creier şi restul viscerelor, între general şi local, între întreg şi părţile 


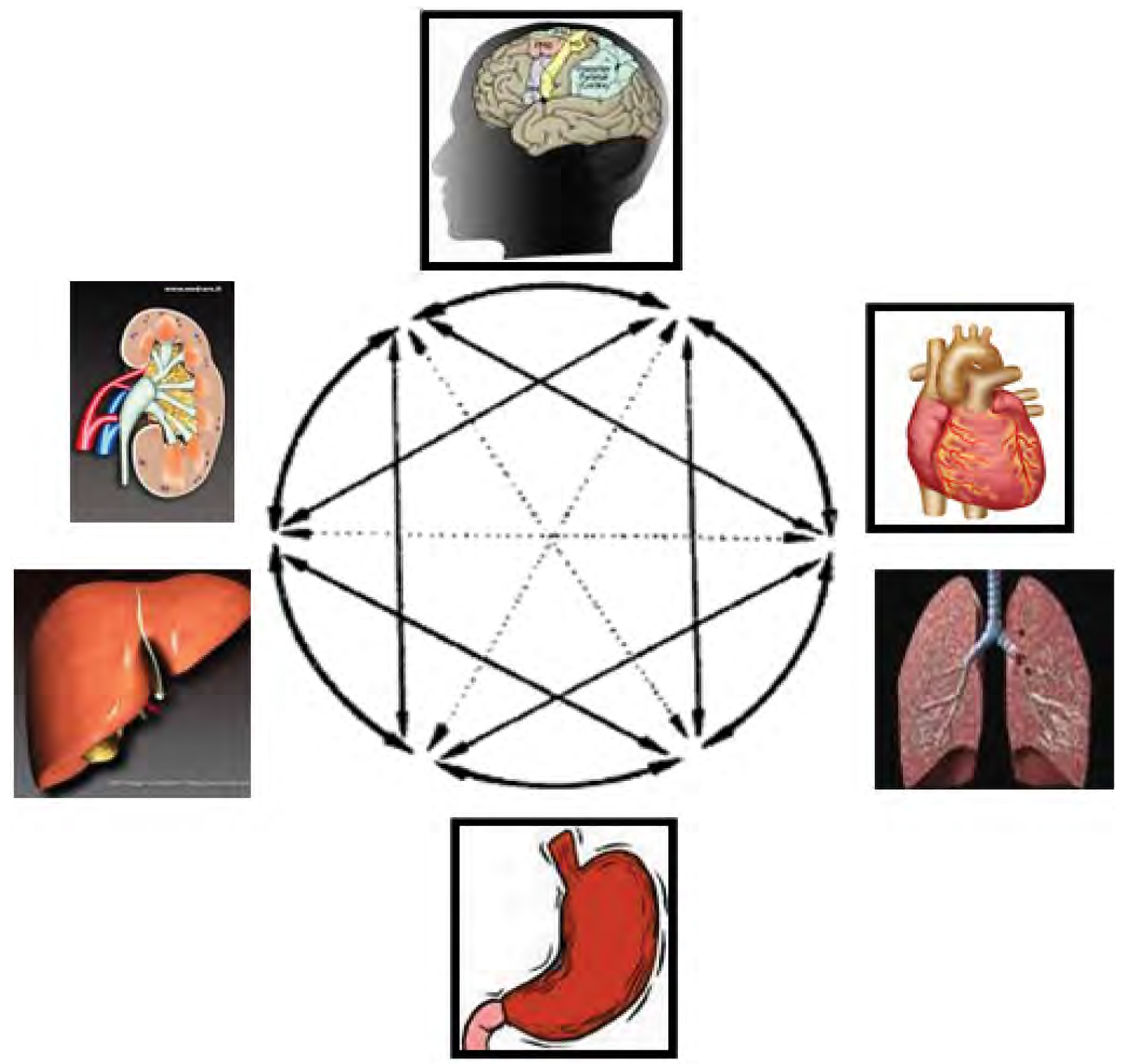

FIGURA 2. Schemă adaptată după Ştefan Odobleja ,,Psihologia consonantistă“ (2, p. 425)

sale. E studiul reflexelor psiho-fizice; ştiinţa interreacţiilor psiho-fizice“.

Există acţiuni interorganice ce se realizează prin intermediul centrilor nervoşi (creier etc.). Există însă şi acţiuni interorganice directe. Fiecare organ are relaţii cu toate celelalte organe, inclusiv cu creierul (fig. 2).

Odobleja afirmă că psihicul aparţine fizicului şi este energetic, iar legăturile între organe s-ar face nu numai prin contact fibrilar. Afirmaţia pe care a făcut-o în urmă cu 81 ani se pare că abia în zilele noastre ar putea fi dovedită. El sublinia atunci că „,elementele veritabile ale fenomenelor psihice sunt invizibile - ca şi elementele sau substratul material al energiilor fizice - şi analoge, dacă nu identice cu acestea din urmă. Procesul psihic nu mai este un fenomen atât de grosier precum cel presupus de apropiere mecanică şi de îndepărtare a fibrelor neuronice - dar un proces de extremă fineţe, un proces energetic. Psihologia este, într-adevăr, fiziologia centrilor nervoşi, dar nu e decât partea cea mai fină, cea mai intimă, cea mai subtilă, a acestei fiziologii, restul e neurologie. Psihologia este o fiziologie fără anatomie, deoarece anatomia sa veritabilă, anatomia psihologică propriu-zisă, microscopia energetică, nu a fost inaugurată până în prezent. Noi nu putem, până la noi date, decât să ne imaginăm mintal, imitându-i pe chimişti şi pe fizicieni, 
care fac acelaşi lucru pentru valenţele, atomii, cuantele, ionii şi electronii lor. Poate că niciodată omul nu va reuşi să vadă şi să constate direct cu simţurile sale - inclusiv cu aparatele care le prelungesc şi le măresc - adevăratul substrat material (anatomic) al psihicului său. Nu vom aştepta progresele anatomiei pentru a crea psihologia: fizicienii şi chimiştii nu au aşteptat nici ei să vadă ionii pentru a studia electricitatea“.

\section{Studii multi şi interdisciplinare}

În discuţia despre modul cum se transmit anumite informaţiile de la donatorul de organe la beneficiar ar mai putea luaţi în consideraţie şi feromonii, grupări chimice, molecule, care, chiar în diluţii foarte mari, au rolul de a transmite semnalele, mesajele diferitelor specii din regnul vegetal şi animal. Termenul de feromon a fost definit de Peter Karlson, Martin Luscher şi Adolf Butenandt. Feromonii sunt percepuţi de organul vomeronazal şi transmişi la hipotalamus. Acest organ conţine celule nervoase (aproximativ 15 neuroni), fiind singurul în contact cu mediul înconjurător. De asemenea, revista „Scientific American“ publică studii care evidenţiază faptul că aceşti feromoni influenţează şi starea de spirit a omului.

Pe lângă posibilele mecanisme de transmitere a unor caracteristici ale personalităţilor de la organe la beneficiari, prezentate mai sus, a mai apărut un aspect: în urma unui transplant pulmonar, beneficiarul a moştenit de la donator o alergie alimentară (la unt de arahide). Aceasta s-a întâmplat la Universitatea din California, la San Diego Medical Center, unde dr. Mazen Odisch, din echipa multidisciplinară care a efectuat transplantul, a explicat că este o situaţie extrem de rară ( 4-5 cazuri de acest tip) în care beneficiarul unui transplant de organ să dobândească o reacţie alergică.

Alţi oameni de ştiinţă care au avut preocupări legate de creierul uman şi fizica cuantică se numără profesorul de psihologie şi psihiatrie Karl H. Pribram (1919-2015), de origine austriacă, de la Georgetown University. Acesta a descoperit capacitatea unică a undelor cuantice de a stoca enorme cantităţi de informaţii în totalitate şi în trei dimensiuni, dar şi de capacitatea creierului nostru de a citi aceste informaţii şi de a crea lumea cu ajutorul lor. După Pribram, creierul este un analizator de frecvenţe de mare finețe şi a mai dovedit că şi alte simţuri ale noastre - mirosul, gustul şi auzul - funcţionează prin analiza frecvenţelor.

Kunio Yasue, specialist în fizică cuantică din Kyoto, Japonia, a elaborat formula matematică care ajută la înţelegerea microproceselor neuronale şi mai arată că procesele creierului au loc la nivel cuantic.

Mari Jibu, de la Facultatea de Anestezie a Universităţii Okayama din Japonia, a formulat şi el teoria că transmiterea mesajelor cuantice din creier trebuie să aibă loc prin câmpuri vibraţionale de-a lungul microtubulilor din celule. Microtubulii ajută la ordonarea energiei discordante şi creează coerenţa globală a undelor corpului - un proces numit „superradianţă“ -, apoi permite acestor semnale coerente să pulseze prin restul corpului.

Poate cele mai apropiate rezultate ale cercetărilor (1980-1990) din întreaga lume, de ideile lui Şt. Odobleja (1939), privind mecanismele de comunicare între organele transplantate şi beneficiar, sunt evidenţiate de savanţii Vladimir Poponin şi Piotr Gariaev care au dovedit că ADN-ul uman influenţează lumea materială, fenomen numit „ADN fantomă“".

Alţi cercetători precum: Fritz Albert Popp, fondator al Institutului Internaţional de Biofizică din Neuss, Germania, fizicienii germani Grazyana Fosar şi Frantz Bludorf, studiind calităţile moleculei $\mathrm{ADN}$, au lansat ideea ,cipului biologic din celulele noastre"; cercetătorii ruşi V. Kaznacheev, V. Burlakov, V. Budakovski au experimentat transmiterea holografică de informaţie morfogenetică; în ultimii ani, dr. Mae-Wan Ho, specialistă în genetică din Hong Kong, lansează teoria coerenței cuantice prin sintagma ,jazz cuantic“.

\section{CONCLUZII}

1. În fiecare organism viu există două niveluri: unul material şi un altul subtil - energie informaţională.

2. Cele două niveluri ale unui organism sunt legate în mod intim unul de celălalt; energia informaţională este nivelul de comandă

3. Savantul român Ştefan Odobleja (19021978) a fost printre primii oameni de ştiinţă care, în opera sa „Psihologia consonantistă“ - o lucrare de psihofizică şi psihosomatică -, a intuit legătura dintre psihic şi lumea cuantică, utilizând 9 legi universale: ale echivalenţei, echilibrului, compensaţiei, reacţiei, oscilaţiei, reversibilităţii, inerţiei, consonanţei, transformării, având la bază fenomenul de rezonanţă. Este primul care a încercat să aplice legea feedback-ului în natură şi societate. 


\section{BIBLIOGRAFIE}

1. lamandescu IB (2015). Consonantist psychosomatics. Revista Medicală Română, vol. 62, nr. 4, pp, 425-426.

2. Odobleja Şt. (1982). Psihologia consonatistă. Ed.Ştiinţifică şi Enciclopedică, Bucureşti

3. Odobleja Şt. (1935). La phonoscopie, nouvelle methode d'exploration clinique. G.Doin et Cie, Editeurs, Paris

4. Popescu N (2016). Psihosomatica consonantistă: Contribuția doctorului Şterfan Odobleja adusă conceptului de psihosomatic. Ed.Universitaria, Craiova.

5. Riga S, Riga D (2009). Cap. 27 - Psihiatrie (pp. 21-24-2172). Minimonografia Ştefan Odobleja (pp. 2148-2149). În: N. Ursea (ed.), Enciclopedia Medicală Românească, sub egida Academiei Române, vol. 3, seç̧iunea V (ştinţele medicale). Ed. Universitară Carol Davila, Bucureşti

6. Riga S, Riga D (2013). Repere în cercetarea psihiatrică românească (pp. 356-427). Minimonografia Ştefan Odobleja (pp. 358-360). În:G.
Corniţiu (ed.). Capitole de istorie a psihiatriei româneşti. Ed. Universităţii, Oradea.

7. Simache A. (2019). Transplant pulmonar cu adaos de alergie la alune. Viaţa Medicală nr. 2, 11 ianuarie, Bucureşti.

8. https://incredibilia.ro/misterul-memoriei-transplant de organe;

9. htpps://saccsiv.wordpress.co/2015/03/26/video-ce-schimbari-bizarese-petrec-cu-primitorul-unui-transplant-de-inima-ce-i-transmite-donatorul-si-nu-doar-în-cazul-inimii/;

10. https://academiadestiintesiterapiicuantice.ro/creierul-uman-si-fizicacuantica/;

11. https://stiintaonline.ro/constiinta-un-efect-al-vibratiei-materiei-rezonanteil;

12. https://www.stiintaonline.ro/misterul-constiintei-si-legatura-dintre-minte-si-lumea-cuan... 